\title{
Two Archean Sm-Nd ages of 3.2 and 2.5 Ga for the Marble Bar Chert, Warrawoona Group, Pilbara Block, Western Australia
}

\author{
MASAyo Minami ${ }^{1}$, Hiroshi Shimizu ${ }^{2}$, AKIMASA MASUdA $^{1}$ and MAMORU AdACHI ${ }^{3}$ \\ ${ }^{1}$ Department of Chemistry, The University of Electro-Communications, 1-5-1, Chofu, Tokyo 182, Japan \\ ${ }^{2}$ Department of Earth Sciences, Faculty of Science, Kumamoto University, Kumamoto 860, Japan \\ ${ }^{3}$ Department of Earth and Planetary Sciences, School of Science, Nagoya University, Nagoya 464-01, Japan
}

(Received March 24, 1995; Accepted July 20, 1995)

\begin{abstract}
Isotopic data of Sm-Nd, La-Ce and $\mathrm{Rb}-\mathrm{Sr}$ systems, rare earth element (REE) abundances and major element compositions are reported for the Archean Marble Bar Chert from the Towers Formation of the Salgash Subgroup, Warrawoona Group, Pilbara Block, Western Australia. The Marble Bar Chert records two Sm-Nd ages; $3.2 \pm 0.3 \mathrm{Ga}$ for red (or black) and white banded cherts and $2.5 \pm 0.2 \mathrm{Ga}$ for yellowish gray cherts. These ages contain relatively large uncertainties and are younger than $3.45 \mathrm{Ga} \mathrm{U}-\mathrm{Pb}$ zircon ages previously reported for the Salgash Subgroup. The results imply some later perturbation in Sm-Nd system of these cherts after their formation. However, the older age of $3.2 \pm 0.3 \mathrm{Ga}$ is close to the $\mathrm{U}-\mathrm{Pb}$ zircon ages for the Salgash Subgroup within analytical errors and therefore can be regarded as the formation time of the banded cherts. On the other hand, the younger age of $2.5 \pm 0.2 \mathrm{Ga}$ for the yellowish gray cherts is thought to reflect the time of later thermal events and the cherts do not retain their original chemical features. The 3.2 Ga Sm-Nd age for the Marble Bar banded cherts is the first Archean record obtained for the Archean cherts; their initial $\varepsilon_{\mathrm{Nd}}$ value of $+1.0 \pm 3.0$ holds the original nature at their formation without severe geochemical disturbance. The obtained mantle-like depleted or chondritic feature at $3.2 \mathrm{Ga}$ for the banded cherts, together with their $\mathrm{SiO}_{2}$ and $\mathrm{Fe}_{2} \mathrm{O}_{3}{ }^{*}$ data and positive $\mathrm{Eu}$ anomalies in REE patterns, suggests substantially large contribution of hydrothermal solution derived from depleted- or chondritic-mantle to the cherts and inorganic origin of the cherts, which contrasts to Phanerozoic biogenic cherts.
\end{abstract}

\section{INTRODUCTION}

Chert is one of the most common sedimentary rocks in the Archean greenstone belts. Geochemical feature of chert reflects the nature of its sources and of its formational environment (e.g., Kolodny and Epstein, 1976; Shimizu and Masuda, 1977; Weis and Wasserburg, 1987a; Shimizu et al., 1991), and those of Archean cherts provide information on the crustal evolution and oceanic environment in the Archean (e.g., Wildman and Haskin, 1973; Nagasawa and Suwa, 1986; Weis and Wasserburg, 1987b; Sugitani, 1992). However, the origin and geochemical features of Archean cherts are poorly understood chiefly because of the very low concentrations of elements other than $\mathrm{Si}$ and partly because of possible disturbance of their original features by later events.

Since many, if not most, Archean rocks have undergone a varying degree of later metamorphism and/or metasomatism, it is necessary to assess that the original features are not disturbed or rearranged by later events for the proper understanding of the Archean geochemical information. Weis and Wasserburg (1987b) reported $\mathrm{Sm}-\mathrm{Nd}$ and $\mathrm{Rb}-\mathrm{Sr}$ isotopic data on the Archean cherts from the Onverwacht Group, the Barberton Mountain Land, South Africa. The reported $2.2 \mathrm{Ga} \mathrm{Rb}-\mathrm{Sr}$ age for the Onverwacht cherts was interpreted as later rehomogenization and recrystallization. The SmNd systematics for the cherts do not provide any strict chronological information, but the Sm-Nd data are thought to reflect an ancient source age of ca. 3.5 Ga. Jahn and Shih (1974) also reported 
$\mathrm{Rb}$-loss for the Onverwacht cherts.

Almost all chert samples for the present study were collected from a chert unit designated as the Marble Bar Chert in the Towers Formation of the Salgash Subgroup, the Warrawoona Group, eastern Pilbara (Fig. 1). The Pilbara Block is a part of the Archean granite-greenstone craton, composed of low-grade metavolcanic and metasedimentary successions and granitic batholiths over approximately 60,000 square kilometers in northwestern Australia. This Block is one of the best preserved early Archean crustal segments (e.g., Lowe, 1980; Taylor and McLennan, 1985), and the nature of this crust should provide an important constraint on models of the early crustal evolution. The supracrustal sequence of the eastern Pilbara is divided into two major groups: the Warrawoona Group that consists mainly of mafic-felsic volcanic (rarely ultramafic) rocks and the Gorge Creek Group that consists mainly of terrigenous sedimentary rocks (Lipple, 1975; Hickman and Lipple, 1975). The stratigraphy of the Warrawoona Group in the Pilbara Supergroup is shown in Table 1.

The age of the Warrawoona Group is estab-

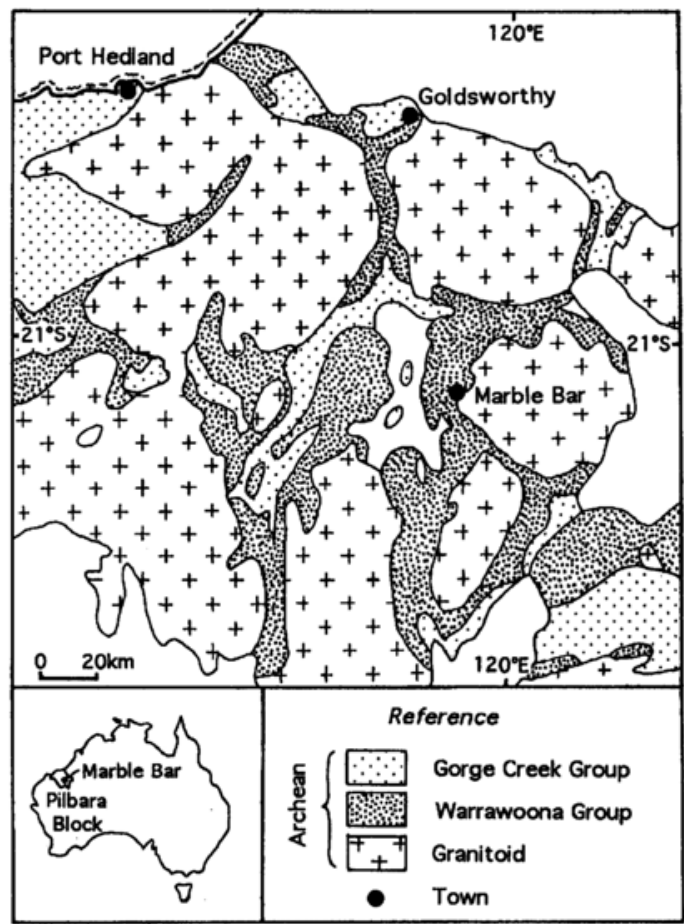

Fig. 1. Geological map of the eastern Pilbara Block, Western Australia (modified from Hickman (1983) and Bickle et al. (1993)).

Table 1. Stratigraphy of Warrawoona Group, Pilbara Block (modified from Hickman, 1983)

\begin{tabular}{|c|c|c|c|}
\hline Subgroup & Formation & Main lithology & Age (Ga) \\
\hline & Wyman Formation & Rhyolite & $3.3 *$ \\
\hline \multirow{5}{*}{ Salgash Subgroup } & Euro Basalt & Basalt and komatiite & \multirow{4}{*}{$3.4^{*}$} \\
\hline & Panorama Formation & Felsic volcanics & \\
\hline & Apex Basalt & Basalt and komatiite & \\
\hline & Towers Formation & Chert and basalt & \\
\hline & Duffer Formation & Felsic volcanics & $3.4-3.5^{*, * *}$ \\
\hline \multirow{3}{*}{ Talga Talga Subgroup } & Mount Ada Basalt & Basalt & \multirow{3}{*}{$3.5-3.7 * * *$} \\
\hline & McPhee Formation & Carbonate schist and chert & \\
\hline & North Star Basalt & Basalt & \\
\hline
\end{tabular}

*Thorpe et al. (1992).

**Pidgeon (1978).

***Hamilton et al. (1981), Jahn et al. (1981), Gruau et al. (1987). 
lished on the basis of Sm-Nd isochron ages of $3.56 \pm 0.03 \mathrm{Ga}$ (Hamilton et al., 1981), $3.57 \pm 0.18$ $\mathrm{Ga}$ (Jahn et al., 1981) and 3.71 $\pm 0.10 \mathrm{Ga}$ (Gruau et al., 1987) on the Talga Talga Subgroup, and $\mathrm{U}-\mathrm{Pb}$ zircon ages of $3.45 \pm 0.02 \mathrm{Ga}$ (Pidgeon, 1978) and $3.47 \pm 0.05 \mathrm{Ga}$ on the Duffer Formation (Thorpe et al., 1992) and $3.45 \mathrm{Ga}$ on the upper Salgash Subgroup (Thorpe et al., 1992). These isotopic ages are consistent with the stratigraphical sequence as shown in Table 1. No geochronological data have been obtained for sedimentary rocks including the Marble Bar Chert in the Pilbara Block.

The main aims of this study are: (1) to establish the age of the Marble Bar Chert of the Salgash Subgroup in the Warrawoona Group, (2) to obtain the information concerning the origin and formational environments of Archean cherts in the Pilbara Block, and (3) to shed more light on the crustal evolution in the Pilbara Block.

\section{SAMPLES}

All chert samples were from the Towers Formation of the Salgash Subgroup, the Warrawoona Group. The 1201- and 1103-series chert samples were collected at the Marble Bar region, and one sample of 1302-A was at the Goldsworthy region to the north of Marble Bar (Fig. 1). The locality of 1103-series samples is about $1 \mathrm{~km}$ east from that of 1201-series samples. Red-white banded cherts are dominant at Marble Bar and the thickness of most bands ranges from 1 to $10 \mathrm{~cm}$. Some bands consist of fine alternations of red and white laminae of ca. 1 to $2 \mathrm{~mm}$. The red or black (dark red) bands consist generally of microcrystalline hematite, goethite, opaque minerals, rhombic carbonate and quartz, whereas the white bands consist mostly of microcrystalline quartz. These red-white banded chert layers are sporadically associated with yellowish (or creamy) gray cherts. Yellowish gray cherts consist largely of microcrystalline quartz commonly associated with mega-quartz. The mega-quartz occurs either as veins of 0.5 to $2 \mathrm{~mm}$ in thickness or as subrounded clots of 0.5 $\mathrm{mm}$ in size. Some yellowish gray cherts are en- riched in carbonaceous matter, sericite, chlorite, and rutile. Sugitani (1992) also reported that minerals contained in banded cherts and yellowish gray cherts from Marble Bar are different.

Analyses were done on both banded cherts (samples 1201-10, -18, -27, -29, 1103-0 and 1302A) and yellowish gray cherts (samples 1201-9, $20,-35,-40,-48$ and 1103-3). Both red (or black) bands and white bands of banded cherts were separately analyzed for samples 1201-10, -18, -27 and -29 , while only red bands were analyzed for samples 1103-0 and 1302-A. For yellowish gray chert sample 1103-3, both gray and yellowish parts were separately analyzed. In this paper, red (or black) band and white band of banded cherts are designated as $\mathrm{R}$ and $\mathrm{W}$, and gray part and yellowish part are as $G$ and $Y$, respectively. The 1201-series samples are all conformably piled up and the samples with smaller sample numbers represent stratigraphically upper or younger ones.

\section{ANALYTiCal Methods}

Chemical procedures used are almost identical to those of Tanaka and Masuda (1982) and Shimizu et al. (1988). Slices of rock samples were crushed into grains, about 3-8 $\mathrm{g}$ of which was collected and powdered. After the powders were decomposed with $\mathrm{HF}, \mathrm{HClO}_{4}$ and $\mathrm{HCl}$ in a teflon beaker, the decomposed solution was divided into two fractions of (A) and (B): (A) for the analysis of REE, $\mathrm{Rb}$ and $\mathrm{Sr}$ abundances and $(\mathrm{B})$ for the analysis of $\mathrm{Nd}, \mathrm{Ce}$ and $\mathrm{Sr}$ isotopic ratios.

$\mathrm{REE}, \mathrm{Rb}$ and $\mathrm{Sr}$ abundances were determined by the isotope dilution method. Spike solutions of $\mathrm{REE}, \mathrm{Rb}$ and $\mathrm{Sr}$ were added to a fraction of (A), then these elements were separated from major elements through an AG50W-X8 cation exchange column with $\mathrm{HCl}$, and measured on a JEOL JMS05RB thermal ionization mass spectrometer.

For a fraction of (B), REE were separated through an AG50W-X8 quartz column with $\alpha$ hydroxy-isobutyric acid ( $\alpha$-HIBA or 2-hydroxy-2methylpropionic acid). The $\mathrm{Nd}$ and $\mathrm{Sr}$ isotopic compositions were measured as $\mathrm{Nd}^{+}$on $\mathrm{Re}$ triple filaments with a VG354 mass spectrometer, and 
$\mathrm{Sr}^{+}$on Ta single filament with a VG Sector54 mass spectrometer, respectively. The $\mathrm{Ce}$ isotopic composition was measured as $\mathrm{CeO}^{+}$on $\mathrm{Re}$ triple filaments with a VG54-38 mass spectrometer. The measured isotopic ratios of $\mathrm{Nd}, \mathrm{Sr}$ and $\mathrm{Ce}$ were normalized against ${ }^{146} \mathrm{Nd} /{ }^{144} \mathrm{Nd}=0.7219,{ }^{86} \mathrm{Sr} /$ ${ }^{88} \mathrm{Sr}=0.1194$ and ${ }^{136} \mathrm{Ce} /{ }^{142} \mathrm{Ce}=0.01688$, respectively. In this study, the isotopic ratios measured for the standard reagents were as follows: ${ }^{143} \mathrm{Nd} /$ ${ }^{144} \mathrm{Nd}$ for Johnson Matthey $\mathrm{Nd}_{2} \mathrm{O}_{3}$ (JMC321, Batch No. $8.810931 \mathrm{~A})$ was $0.511105 \pm 0.000009(2 \sigma)$ on 12 measurements; ${ }^{87} \mathrm{Sr} /{ }^{86} \mathrm{Sr}$ for NBS987 $\mathrm{Sr}$ was $0.71022 \pm 0.00002(2 \sigma)$ on 18 measurements; ${ }^{138} \mathrm{Ce} /{ }^{142} \mathrm{Ce}$ for Johnson Matthey $\mathrm{CeO}_{2}$ (JMC304) was $0.0225736 \pm 0.0000009(2 \sigma)$ on 23 measurements.

The $\mathrm{Nd}$ and $\mathrm{Ce}$ isotopic ratios were normalized relative to chondritic values and presented using the $\varepsilon$ notation as described by DePaolo and Wasserburg (1976); $\varepsilon(T)=\left(R_{\mathrm{m}}(T) / R_{\mathrm{CHUR}}(T)-\right.$ 1) $\times 10^{4}$, where $R_{\mathrm{m}}(T)$ and $R_{\mathrm{CHUR}}(T)$ refer to the isotopic ratios of ${ }^{143} \mathrm{Nd} /{ }^{144} \mathrm{Nd}$ or ${ }^{138} \mathrm{Ce} /{ }^{142} \mathrm{Ce}$ for a sample $(\mathrm{m})$ and chondritic uniform reservoir (CHUR) at time $T$ ( $T=0$ for present). Present values of $\left({ }^{143} \mathrm{Nd} /{ }^{144} \mathrm{Nd}\right)_{\mathrm{CHUR}}$ and $\left({ }^{138} \mathrm{Ce} /{ }^{142} \mathrm{Ce}\right)_{\mathrm{CHUR}}$ are taken to be 0.512638 (Wasserburg et al., 1981) and 0.0225722 (Shimizu et al., 1984, 1988), respectively.

Major element compositions were determined by using a Shimazu scanning type X-ray fluorescence spectrometer (VF320A). The fusion glasses made from the mixture of samples and flux $\left(\mathrm{Li}_{2} \mathrm{~B}_{4} \mathrm{O}_{7}\right)$ in the proportion of 1:9 were used for the measurement. Calibration was made with the standard rocks prepared by the Geological Survey of Japan, including chert standard rock JCh-1.

\section{RESULTS}

\section{Major element compositions}

Major element data are presented in Table 2. Chert samples consist mostly of $\mathrm{SiO}_{2}$ and $\mathrm{Fe}_{2} \mathrm{O}_{3}$ * (total iron as $\mathrm{Fe}_{2} \mathrm{O}_{3}$ ), and the concentrations of elements other than $\mathrm{Si}$ and $\mathrm{Fe}$ are very low. The banded cherts are marked by high $\mathrm{Fe}_{2} \mathrm{O}_{3}$ * concentrations; particularly the red or black bands of clearly banded cherts are enriched in $\mathrm{Fe}_{2} \mathrm{O}_{3}{ }^{*}$. Concentrations of $\mathrm{Fe}_{2} \mathrm{O}_{3}$ * in some red bands are higher than $10 \%$. On the other hand, yellowish gray cherts generally tend to show lower concentrations of $\mathrm{Fe}_{2} \mathrm{O}_{3}{ }^{*}$ (<ca. 1\%) and higher concentrations of $\mathrm{Al}_{2} \mathrm{O}_{3}$ (>ca. $0.1 \%$ ) than white bands of banded cherts, which have almost the same concentrations of $\mathrm{SiO}_{2}$ as yellowish gray cherts.

Figure 2 shows the $\mathrm{SiO}_{2}-\mathrm{Fe}_{2} \mathrm{O}_{3}{ }^{*}$ diagram for Archean cherts from the Pilbara Block, together with Phanerozoic biogenic cherts from the MinoAshio Terrane, central Japan and deep-sea cherts from the Caribbean Sea. Yamamoto $(1987,1991)$ showed that biogenic cherts, hydrothermal cherts and volcanogenic siliceous rocks are plotted in three different regions in the $\mathrm{SiO}_{2}-\mathrm{Fe}_{2} \mathrm{O}_{3} *$ diagram: the region around the dotted line $\left(\mathrm{SiO}_{2}+\right.$ $4.8 \mathrm{Fe}_{2} \mathrm{O}_{3} * 100 \%$ ) in Fig. 2 for the first cherts, the region enriched in $\mathrm{Fe}$ for the second cherts, and the region poor in $\mathrm{Fe}$ for the third cherts, respectively. All Pilbara cherts studied here fall into the region of hydrothermal cherts, and clearly negative correlation between $\mathrm{SiO}_{2}$ and $\mathrm{Fe}_{2} \mathrm{O}_{3}{ }^{*}$, where $\mathrm{SiO}_{2}+\mathrm{Fe}_{2} \mathrm{O}_{3} * 99.5 \%$, is found. These



Fig. 2. $\mathrm{SiO}_{2}$ against total iron as $\mathrm{Fe}_{2} \mathrm{O}_{3}$ in Archean cherts from Pilbara, Triassic cherts from Japan and deep-sea from the Caribbean Sea. Sample descriptions for these Phanerozoic cherts are given in Shimizu et al. (1991). The dotted regression line denotes the data from the Mino Terrane (Yamamoto, 1987, 1991). 


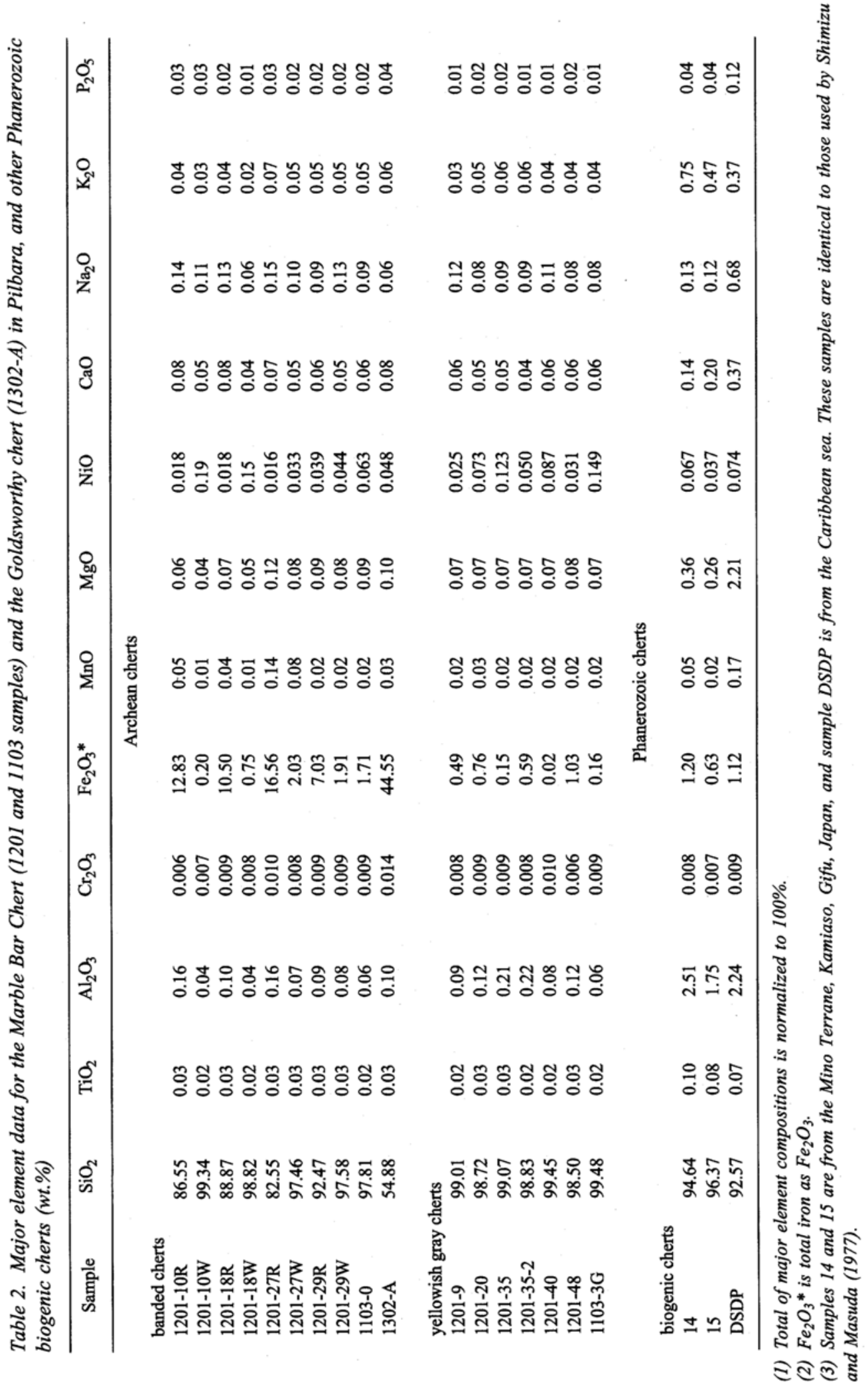








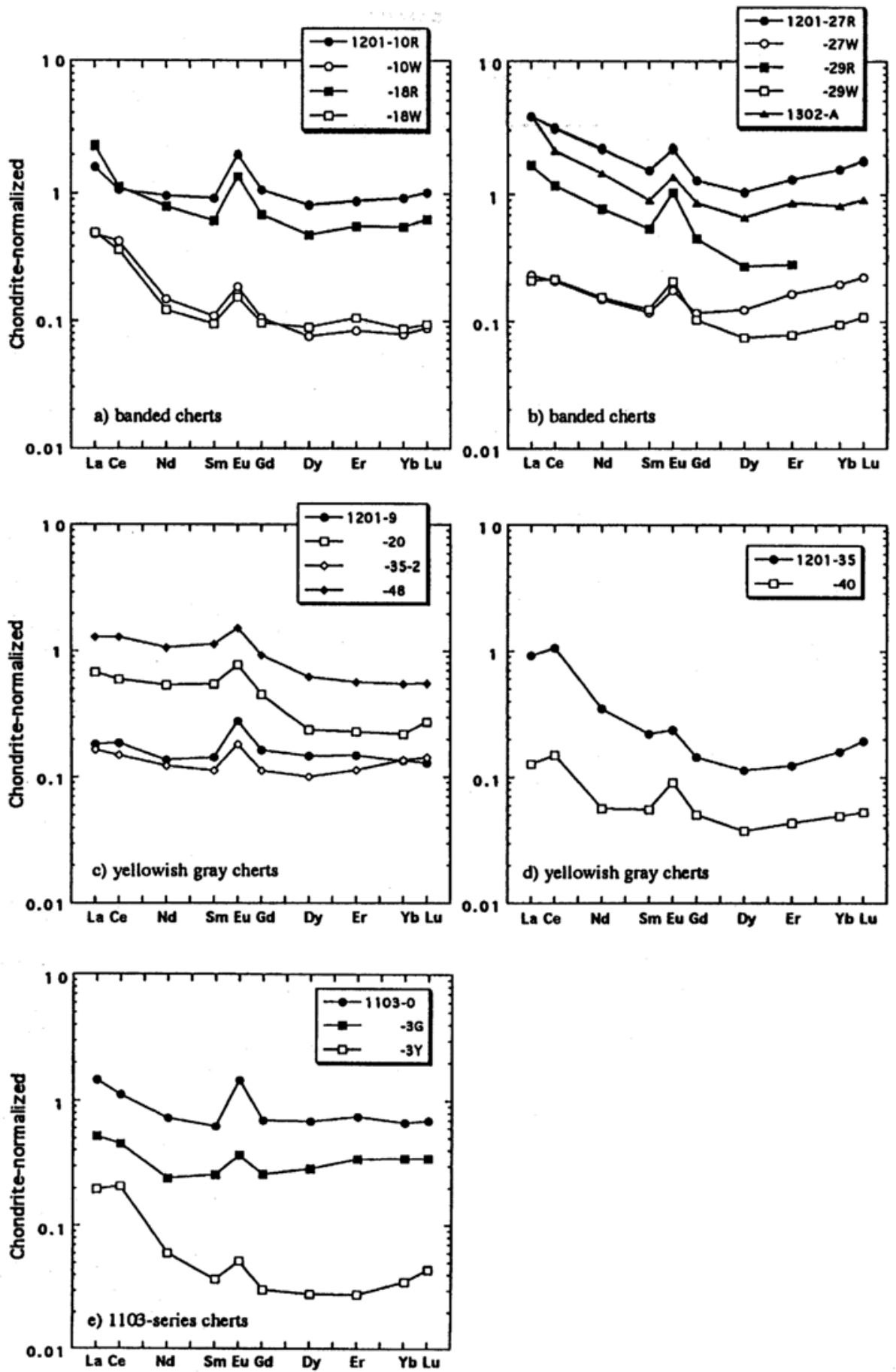

Fig. 3. Chondrite-normalized REE patterns of cherts from the Marble Bar region and the Goldsworthy region. (a) Marble Bar banded cherts (1201-10R, -10W, $-18 R$ and -18W), (b) Marble Bar banded cherts (1201-27R, $-27 W,-29 R$ and $-29 W)$ and Goldsworthy chert (1302-A), (c) Marble Bar yellowish gray cherts (1201-9, -20, -35-2 and -48), (d) Marble Bar yellowish gray cherts with positive Ce anomalies (1201-35 and -40), and (e) Marble Bar 1103-series cherts. 
data are consistent with geochemical features of the Marble Bar Chert reported by Sugitani (1992), who stated that most silica and iron in the Marble Bar Chert may have been derived from hydrothermal solutions enriched in $\mathrm{Si}$ as well as $\mathrm{Fe}$.

\section{REE abundances}

REE abundances are given in Table 3 and chondrite-normalized REE patterns are shown in Figs. 3(a)-(e). REE abundances in the Leedey chondrite (Masuda et al., 1973) are employed as the normalizing values. The REE patterns show the following features:

(1) In general, almost all REE patterns are characterized by relatively horizontal span, and gently V-shaped REE patterns are observed for some of banded cherts and yellowish gray cherts.

(2) Positive Eu anomalies are observed for all samples. The positive Eu anomalies may indicate that submarine hydrothermal sources were important or even dominant for the REE, because the $\mathrm{Eu}$ anomalies were most likely produced by reducing hydrothermal solutions that were enriched in $\mathrm{Eu}^{2+}$ (Graf, 1978; Fryer et al., 1979; Derry and Jacobsen, 1990). The banded cherts, particularly red bands of them, generally show larger positive $\mathrm{Eu}$ anomalies $\left(\mathrm{Eu} / \mathrm{Eu}^{*}=1.5-2.2\right)$ than yellowish gray cherts $\left(\mathrm{Eu} / \mathrm{Eu}^{*}=1.3-1.8\right)$ shown in Table 3, indicating that larger contribution of hydrothermal components to banded cherts relative to yellowish gray cherts.

(3) REE patterns for red bands of some banded chert samples show slightly negative Ce deviations or positive La deviations, while those for white bands show slightly positive Ce deviations or negative La deviations. Some yellowish gray cherts (samples 1201-35, -40 and 1103-3Y) also show slightly positive $\mathrm{Ce}$ anomalies. Relatively large


Fig. 4. $\mathrm{REE}$ (La, $\mathrm{Ce}, \mathrm{Nd}$ and $\mathrm{Sm}$ ) against $\mathrm{Fe}_{2} \mathrm{O}_{3}$ *. Symbols are identical to those in Fig. 2. 
positive Ce anomalies are observed for LREE-enriched patterns.

(4) REE patterns of banded cherts show a Wtype zigzag feature in heavy REE pointing downward at $\mathrm{Dy}$ and $\mathrm{Yb}$ and upward at Er. The Wtype zigzag features are often observed in REE patterns of the natural waters and related materials, and thought to reflect the W-typed lanthanide tetrad effect (Masuda and Ikeuchi, 1979; Masuda et al., 1987). Masuda et al. (1987) reported that the occurrence of the tetrad effect in nature has a significant relation to the history of contact or reaction with water. The W-typed tetrad effect for banded cherts implies precipitation directly from water. On the other hand, REE patterns of yellowish gray cherts do not show clear tetrad effect, implying that their precipitation environment was different from that of banded cherts or that their REE features were disturbed by any event after deposition.

Relationships of $\mathrm{Fe}_{2} \mathrm{O}_{3}{ }^{*}$ against $\mathrm{REE}$ ( $\mathrm{La}, \mathrm{Ce}$, $\mathrm{Nd}$ and $\mathrm{Sm}$ ) are shown in Fig. 4. In $\mathrm{Fe}_{2} \mathrm{O}_{3}{ }^{*}$-REE diagrams, REE contents tend to increase with the increase of $\mathrm{Fe}_{2} \mathrm{O}_{3}$ * composition, but $\mathrm{Fe}_{2} \mathrm{O}_{3}{ }^{*}$-REE correlation is different between banded cherts and yellowish gray cherts. The correlation lines for the yellowish gray cherts pass in the higher REE sides (or in the lower $\mathrm{Fe}_{2} \mathrm{O}_{3}$ * side) than the corresponding lines for the banded cherts. The implication inferred from the results will be discussed later.

\section{Isotopic ratios}

The Sm-Nd, La-Ce, and $\mathrm{Rb}-\mathrm{Sr}$ isotopic data are presented in Tables 4 and 5. The decay constants used in the following discussion are $\lambda_{\alpha}{ }^{147} \mathrm{Sm}=6.54 \times 10^{-12} \mathrm{yr}^{-1}, \lambda_{\beta}{ }^{138} \mathrm{La}=2.33 \times$ $10^{-12} \mathrm{yr}^{-1}, \lambda_{\mathrm{EC}}{ }^{138} \mathrm{La}=4.11 \times 10^{-12} \mathrm{yr}^{-1}$, and

Table 4. Sm-Nd and La-Ce isotopic data for the Marble Bar. Chert and the Goldsworthy chert

\begin{tabular}{lcccc}
\hline \multicolumn{1}{c}{ Sample } & ${ }^{147} \mathrm{Sm} /{ }^{144} \mathrm{Nd}$ & ${ }^{143} \mathrm{Nd} /{ }^{144} \mathrm{Nd}$ & ${ }^{138} \mathrm{La} /{ }^{142} \mathrm{Ce}$ & ${ }^{138} \mathrm{Ce} /{ }^{142} \mathrm{Ce}$ \\
\hline banded cherts & & & & - \\
$1201-10 \mathrm{R}$ & 0.1856 & $0.512448 \pm 11$ & - & - \\
$1201-10 \mathrm{~W}$ & 0.1422 & $0.511504 \pm 19$ & - & - \\
$1201-18 \mathrm{R}$ & 0.1519 & $0.511735 \pm 9$ & - & - \\
$1201-18 \mathrm{~W}$ & 0.1498 & $0.511739 \pm 11$ & - & $0.0225763 \pm 14$ \\
$1201-27 \mathrm{R}$ & 0.1349 & $0.511342 \pm 6$ & 0.003870 & $0.0225742 \pm 88$ \\
$1201-27 \mathrm{~W}$ & 0.1528 & $0.511736 \pm 11$ & 0.003540 & $0.0225825 \pm 24$ \\
$1201-29 \mathrm{R}$ & 0.1374 & $0.511474 \pm 10$ & 0.004521 & $0.0225788 \pm 65$ \\
$1201-29 W$ & 0.1551 & $0.511774 \pm 10$ & 0.003109 & $-0225803 \pm 25$ \\
$1103-0$ & 0.1653 & $0.512137 \pm 9$ & 0.004154 & - \\
$1302-\mathrm{A}$ & 0.1209 & $0.511055 \pm 8$ & 0.005616 & $0.0225941 \pm 16$ \\
& & & & - \\
yellowish gray cherts & 0.2062 & $0.512483 \pm 10$ & - & $-0.0225778 \pm 69$ \\
$1201-9$ & 0.1968 & $0.512398 \pm 8$ & 0.003590 & - \\
$1201-20$ & 0.1225 & $0.511120 \pm 8$ & - & - \\
$1201-35$ & 0.1783 & $0.512049 \pm 9$ & 0.003479 & $0.0225765 \pm 27$ \\
$1201-35-2$ & 0.1906 & $0.512318 \pm 13$ & - & - \\
$1201-40$ & 0.2063 & $0.512492 \pm 7$ & 0.003157 & $0.0225745 \pm 23$ \\
$1201-48$ & 0.2057 & $0.512608 \pm 14$ & - & - \\
$1103-3 \mathrm{G}$ & 0.1192 & $0.511252 \pm 17$ & - & - \\
$1103-3 \mathrm{Y}$ & & &
\end{tabular}

(1) Errors of ${ }^{147} \mathrm{Sm} / 144 \mathrm{Nd}$ and ${ }^{138} \mathrm{La} /{ }^{142} \mathrm{Ce}$ ratios are $0.5 \%$.

(2) Errors of $\mathrm{Nd}$ and Ce isotopic data are $2 \sigma_{m}$ and correspond to the last significant figures.

(3) $\mathrm{Nd}$ isotopic ratios are corrected values relative to ${ }^{143} \mathrm{Nd} /{ }^{144} \mathrm{Nd}=0.51112$ for JMC321 and 0.511858 for La Jolla $\mathrm{Nd}$ standards.

(4) Ce isotopic ratios are corrected values relative to ${ }^{138} \mathrm{Ce} /{ }^{142} \mathrm{Ce}=0.0225762$ for JMC304 Ce standard. 
Table 5. Rb-Sr isotopic data for the Marble Bar Chert and the Goldsworthy chert

\begin{tabular}{llccc}
\hline \multicolumn{1}{c}{ Sample } & $\mathrm{Rb}(\mathrm{ppm})$ & $\mathrm{Sr}(\mathrm{ppm})$ & ${ }^{87} \mathrm{Rb} /{ }^{86} \mathrm{Sr}$ & ${ }^{87} \mathrm{Sr} /{ }^{86} \mathrm{Sr}$ \\
\hline banded cherts & & & & \\
$1201-10 \mathrm{R}$ & 0.0710 & 2.34 & 0.0879 & $0.72302 \pm 2$ \\
$1201-10 \mathrm{~W}$ & 0.0342 & 0.556 & 0.1784 & $0.72481 \pm 5$ \\
$1201-18 \mathrm{R}$ & 0.0302 & 0.870 & 0.1005 & $0.72237 \pm 3$ \\
$1201-18 \mathrm{~W}$ & 0.0175 & 0.340 & 0.1491 & $0.72344 \pm 18$ \\
$1201-27 \mathrm{R}$ & 0.317 & 12.5 & 0.0735 & $0.72230 \pm 2$ \\
$1201-27 \mathrm{~W}$ & 0.103 & 1.66 & 0.1798 & $0.72461 \pm 2$ \\
$1103-0$ & 0.0177 & 0.862 & 0.0595 & $0.71580 \pm 2$ \\
$1302-\mathrm{A}$ & 0.211 & 1.25 & 0.4778 & $0.71626 \pm 2$ \\
& & & & \\
yellowish gray cherts & & & & \\
$1201-9$ & 0.0169 & 0.417 & 0.1174 & $0.72303 \pm 9$ \\
$1201-20$ & 0.0765 & 1.69 & 0.1312 & $0.73017 \pm 2$ \\
$1201-35-2$ & 0.873 & 0.717 & 3.554 & $0.79943 \pm 6$ \\
$1201-40$ & 0.0271 & 0.362 & 0.2169 & $0.72359 \pm 12$ \\
$1201-48$ & 0.118 & 2.202 & 0.1553 & $0.72572 \pm 6$ \\
$1103-3 \mathrm{G}$ & 0.0662 & 0.492 & 0.3901 & $0.72755 \pm 16$ \\
$1103-3 \mathrm{Y}$ & 0.112 & 0.411 & 0.7892 & $0.71850 \pm 17$ \\
\hline
\end{tabular}

(1) Errors of ${ }^{87} \mathrm{Rb}{ }^{86} \mathrm{Sr}$ ratio are $0.5 \%$.

(2) Errors of Sr isotopic data are $2 \sigma_{m}$ and correspond to the last significant figures.

(3) Sr isotopic ratios are corrected values relative to ${ }^{87} \mathrm{Sr}{ }^{86} \mathrm{Sr}=0.71023$ for NBS987 Sr standard.

$\lambda_{\beta}{ }^{87} \mathrm{Rb}=1.42 \times 10^{-11} \mathrm{yr}^{-1}$ (Lugmair and Marti, 1978; Makishima et al., 1993; Nakai, 1988; Steiger and Jäger, 1977; respectively).

In the ${ }^{143} \mathrm{Nd} /{ }^{144} \mathrm{Nd}-{ }^{147} \mathrm{Sm} /{ }^{144} \mathrm{Nd}$ diagram (Fig. 5(a)), eight points of banded cherts from 1201series samples $(1201-10 \mathrm{R},-10 \mathrm{~W},-18 \mathrm{R},-18 \mathrm{~W}$, $27 \mathrm{R},-27 \mathrm{~W},-29 \mathrm{R}$ and $-29 \mathrm{~W}$ ) fall on a straight line, which gives an age of $3.23 \pm 0.29 \mathrm{Ga}(2 \sigma)$ with an initial ${ }^{143} \mathrm{Nd} /{ }^{144} \mathrm{Nd}$ ratio of $0.50849 \pm 0.00015(2 \sigma)$ $\left[\varepsilon_{\mathrm{Nd}}(3.23 \mathrm{Ga})=+1.0 \pm 3.0\right.$ ] by York's regression analysis (York, 1966). Sm-Nd data for other banded cherts $1103-0$ and 1302-A also fall on or near the $3.23 \mathrm{Ga}$ line. The age of $3.40 \pm 0.27 \mathrm{Ga}$ $(2 \sigma)$ with an initial ${ }^{143} \mathrm{Nd} /{ }^{144} \mathrm{Nd}$ ratio of 0.50834 $\pm 0.00013(2 \sigma)\left[\varepsilon_{\mathrm{Nd}}(3.40 \mathrm{Ga})=+2.4 \pm 2.6\right]$ is obtained from the regression line for ten Sm-Nd data of banded cherts including 1103-0 and 1302-A.

Among six points representing yellowish gray cherts of 1201-series samples (1201-9, -20, -35, $-35-2,-40$ and -48 ), only sample $1201-35$ falls on the $3.23 \mathrm{Ga}$ line defined by banded chert, but other data are scattered far from the line. The line for the 1201 yellowish gray cherts gives a younger age of $2.54 \pm 0.20 \mathrm{Ga}(2 \sigma)$ with $\varepsilon_{\mathrm{Nd}}(2.54 \mathrm{Ga})=$ $-5.4 \pm 2.0$. Sm-Nd data for other yellowish gray cherts of 1103-3G and -3Y also fall near the 2.5 $\mathrm{Ga}$ line. If these two data are combined, an age of $2.45 \pm 0.22 \mathrm{Ga}(2 \sigma)$ is obtained. Weis and Wasserburg (1987b) reported Sm-Nd data for one sample of dark gray-black chert, with patches of coarser recrystallized material, from the Towers Formation of the Warrawoona Group at North Pole. The Sm-Nd data point of this chert is plotted near the regression line for the yellowish gray chert from Marble Bar.

In the ${ }^{138} \mathrm{Ce} /{ }^{142} \mathrm{Ce}-{ }^{138} \mathrm{La} /{ }^{142} \mathrm{Ce}$ diagram (Fig. $5(\mathrm{~b})$ ), the points of yellowish gray cherts appear to fall close to the $2.5 \mathrm{Ga}$ reference line and many of the points of banded cherts are plotted around the $3.2 \mathrm{Ga}$ reference line, although ${ }^{138} \mathrm{Ce} /{ }^{142} \mathrm{Ce}$ ratios show large analytical errors. The average initial $\varepsilon_{\mathrm{Ce}}$ for the yellowish gray cherts at $2.5 \mathrm{Ga}$ is +0.8 , while that for the banded cherts at $3.2 \mathrm{Ga}$ is calculated to be -0.9 except sample $1201-29 \mathrm{~W}$, whose point deviates from the $3.2 \mathrm{Ga}$ line. 


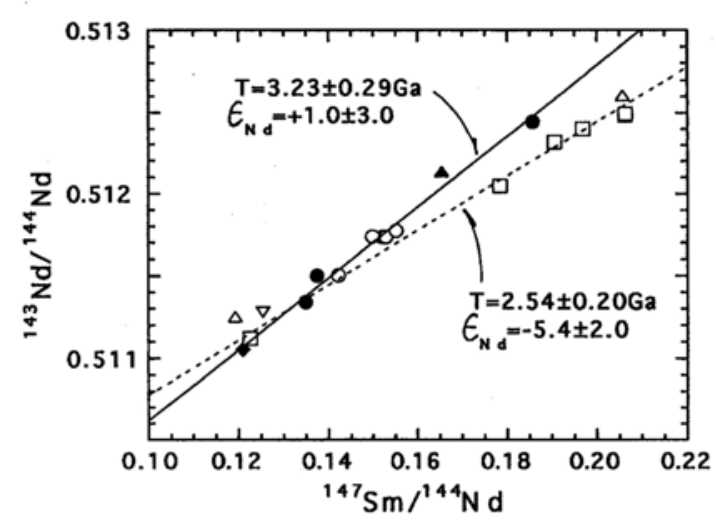

(a)

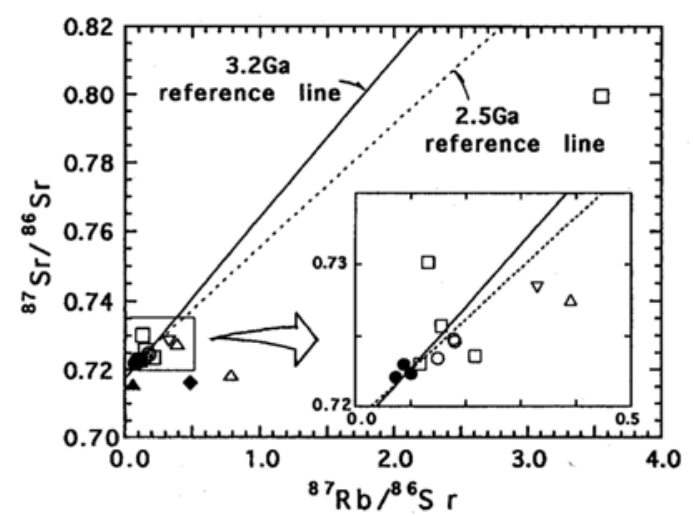

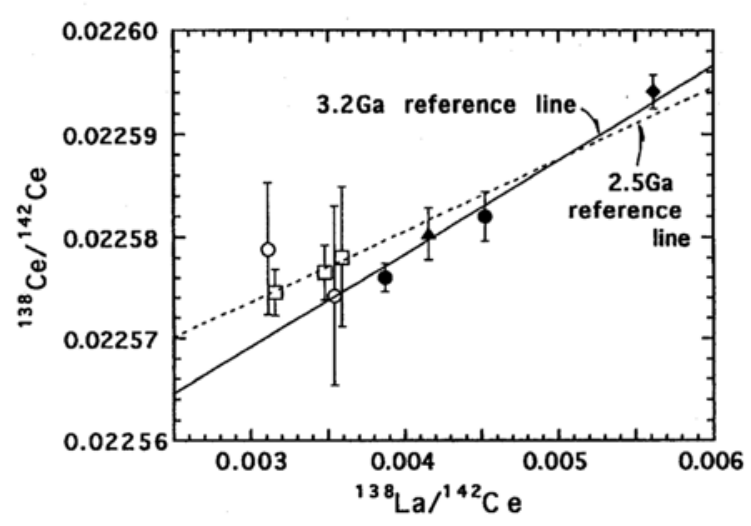

(b)

(c)

Fig. 5. Isochron plots for the Marble Bar Chert and the Goldsworthy chert. (a) ${ }^{143} \mathrm{Nd} /{ }^{144} \mathrm{Nd}-{ }^{147} \mathrm{Sm} /{ }^{144} \mathrm{Nd}$ plot, together with data (reverse open triangle) from the North Pole chert reported by Weis and Wasserburg (1987b). Symbols for the Marble Bar Chert and the Goldsworthy chert are identical to those to Fig. 2 . (b) ${ }^{138} \mathrm{Ce}^{142} \mathrm{Ce}-$ ${ }^{138} \mathrm{La} /{ }^{142} \mathrm{Ce}$ plot. Symbols are identical to those in Fig. $5(\mathrm{a}) .\left(\right.$ c) ${ }^{87} \mathrm{Rb} / 86 \mathrm{Sr}-{ }^{87} \mathrm{Sr} / 86 \mathrm{Sr}$ plot. Symbols are identical to those in Fig. 5(a).

In the ${ }^{87} \mathrm{Rb} /{ }^{86} \mathrm{Sr}-{ }^{87} \mathrm{Sr} /{ }^{86} \mathrm{Sr}$ diagram (Fig. $5(\mathrm{c})$ ), a strict isochron is not drawn for the Marble Bar Chert. The ${ }^{87} \mathrm{Sr} /{ }^{86} \mathrm{Sr}$ ratios of 1201 banded cherts are plotted in a narrow range from 0.7223 to 0.7248 , whereas ${ }^{87} \mathrm{Sr} /{ }^{86} \mathrm{Sr}$ ratios of 1201 yellowish gray cherts are scattered from 0.723 to 0.800 . As shown in Fig. 5(c), deviations from the $3.2 \mathrm{Ga}$ reference line are smaller for the 1201 banded cherts than for the 1201 yellowish gray cherts. This result may indicate larger perturbation by later alteration for the yellowish gray cherts than for the banded cherts.

\section{Discussion}

Two ages obtained for the Marble Bar Chert

No geochronological data have been reported for the Marble Bar Chert in the Towers Formation of the lower Salgash Subgroup. On the other hand, it has been reported that the age of the upper Salgash Subgroup was $3.45 \mathrm{Ga}$ (U-Pb zircon age; Thorpe et al., 1992) and that of the Duffer Formation overlain by the Towers Formation was 3.45 or $3.47 \mathrm{Ga}$ (U-Pb zircon ages; Pidgeon, 1978; Thorpe et al., 1992), as shown in Table 1. In ad- 
dition, widespread thermal events in the early Proterozoic were also reported for the Pilbara Block (Oversby, 1976; Richards, 1978; Pidgeon, 1978; Jahn et al., 1981).

Geochronological data for the Marble Bar Chert are first reported here and it is found that the Marble Bar Chert records two Sm-Nd ages; $3.2 \pm 0.3 \mathrm{Ga}$ for the banded cherts and $2.5 \pm 0.2$ $\mathrm{Ga}$ for the yellowish gray cherts. These Sm-Nd ages are younger than $3.45 \mathrm{Ga} \mathrm{U}-\mathrm{Pb}$ zircon age for the upper Salgash Subgroup reported by Thorpe et al. (1992), although our Sm-Nd age has somewhat larger uncertainties. Some perturbations by later events for the cherts are suggested by relatively large uncertainties in $\mathrm{Sm}-\mathrm{Nd}$ ages and the younger Sm-Nd ages than the $3.45 \mathrm{Ga} \mathrm{U}-\mathrm{Pb}$ zircon age previously reported for the upper Salgash Subgroup. The $3.2 \pm 0.3 \mathrm{Ga}$ Sm-Nd age for the banded cherts is, however, close to the $3.45 \mathrm{Ga} \mathrm{U}-\mathrm{Pb}$ age within analytical errors and is considered to reflect the formational age of the banded cherts. On the other hand, the $2.5 \mathrm{Ga} \mathrm{Sm}$ $\mathrm{Nd}$ age for the yellowish gray cherts is thought to correspond to the time of metasomatism associated with the widespread thermal events in the early Proterozoic in Pilbara, as reported by Oversby (1976), Richards (1978), Pidgeon (1978) and Jahn et al. (1981). Pidgeon (1978) reported zircon $\mathrm{U}-\mathrm{Pb}$ age of $3.5 \mathrm{Ga}$ and $\mathrm{Rb}-\mathrm{Sr}$ whole rock reference age of $2.3 \mathrm{Ga}$ for dacite from the Duffer Formation (Table 1), interpreting the U-Pb age as the formational time of the dacite and the $\mathrm{Rb}$ $\mathrm{Sr}$ age as reflecting an opening of the $\mathrm{Rb}-\mathrm{Sr}$ system during later geological event such as lowgrade hydrothermal alteration. Jahn et al. (1981) also reported 2.3-2.4 Ga $\mathrm{Rb}-\mathrm{Sr}$ ages for dacites from the Panorama Formation and rhyolites from the Wyman Formation besides $3.6 \mathrm{Ga} \mathrm{Rb}-\mathrm{Sr}$ and $\mathrm{Sm}-\mathrm{Nd}$ ages for silicic volcanics from the upper member of North Star Basalt (Table 1), suggesting that the younger $\mathrm{Rb}-\mathrm{Sr}$ ages of $2.3-2.4 \mathrm{Ga}$ represent the time of metasomatism associated with the widespread thermal events in this region about 2.3-2.4 Ga.

The results of $\mathrm{La}-\mathrm{Ce}$ and $\mathrm{Rb}-\mathrm{Sr}$ systems appear to be consistent with that of Sm-Nd system.
The La-Ce isotopic data for the banded cherts and yellowish gray cherts are plotted around the 3.2 and $2.5 \mathrm{Ga}$ reference lines, respectively. Wider scattering of $\mathrm{Rb}-\mathrm{Sr}$ data for the yellowish gray cherts than those of the banded cherts indicates that the degree of perturbation is larger for the yellowish gray cherts than the banded cherts in the $\mathrm{Rb}-\mathrm{Sr}$ system.

\section{Original geochemical features of the Marble Bar Chert}

As noted above, Sm-Nd and La-Ce systems of the Marble Bar banded cherts are considered to have suffered little disturbance after the deposition at $3.2 \mathrm{Ga}$. Therefore, the initial $\varepsilon_{\mathrm{Nd}}$ and $\varepsilon_{\mathrm{Ce}}$ values for the Marble Bar banded cherts essentially reflect their original and intrinsic features. The calculated initial $\varepsilon_{\mathrm{Nd}}$ and $\varepsilon_{\mathrm{Ce}}$ values at $3.2 \mathrm{Ga}$ for these cherts are $+1.0 \pm 3.0$ and $-0.9 \pm 1.3$, suggesting that their sources had mantle-like depleted or nearly chondritic isotopic ratios at $3.2 \mathrm{Ga}$. The LREEdepleted or nearly chondritic nature for the Archean Pilbara was already suggested by Gruau et al. (1987). They reported Sm-Nd data on Archean komatiites, high-Mg basalts and tholeiites of the Talga-Talga Subgroup, the Warrawoona Group, noting that source regions, i.e., mantle source itself, for the Pilbara volcanic rocks were isotopically heterogeneous with $\varepsilon_{\mathrm{Nd}}$ (ca. $3.5 \mathrm{Ga}$ ) values ranging from at least 0 to +4.0 . It is noted that LREE-depleted or nearly chondritic features were suggested for both cherts and basic and ultramafic volcanics; i.e., sources for both of them may be derived from depleted or nearly chondritic mantle.

Degrees of Eu anomalies in the REE patterns of the Marble Bar Chert are plotted as a function of age in Fig. 6, together with data of some Phanerozoic and other Precambrian cherts. All of the Archean cherts have larger positive Eu anomalies than any of the Phanerozoic cherts. There appears to be a general decrease in $\mathrm{Eu} / \mathrm{Eu}^{*}$ with time, similar to the result for Precambrian banded iron formations (BIFs) by Derry and Jacobsen (1990). They suggested that Fe and REE in Precambrian BIFs were derived from subma- 




Fig. 6. Eu anomalies in cherts as a function of age. Data of the Phanerozoic cherts are taken from Shimizu and Masuda (1977). Symbols for the Marble Bar Chert, the Goldsworthy chert and the Phanerozoic cherts are identical to those in Fig. 2. Other symbols: closed square, Archean chert from Gorge Creek Group, Pilbara (Shimizu et al., 1991); open rhombus, Proterozoic Gunflint chert from Canada.

rine hydrothermal systems.

All of major element $\left(\mathrm{SiO}_{2}-\mathrm{Fe}_{2} \mathrm{O}_{3}\right.$ * correlation), REE (positive Eu anomaly), and isotopic data obtained in this study imply substantially large contribution of hydrothermal sources derived from mantle-related rocks to the Marble Bar banded cherts. This is consistent with that obtained by Sugitani (1992), who concluded that the formation of Pilbara cherts were caused by rapid precipitation of hydrothermally-derived $\mathrm{Fe}$ and $\mathrm{Si}$.

\section{Ce anomaly}

The Phanerozoic ferromanganese nodules and deep-sea cherts are characterized by remarkable positive and negative $\mathrm{Ce}$ anomalies, respectively, due to the different chemical behavior of $\mathrm{Ce}$ (IV) from other REE(III) as a result of oxidation of Ce. A difference in Ce behavior between Proterozoic and Archean oceans was pointed out by Fryer (1977) who showed that there are Ce anomalies in Proterozoic chemical sediments as old as 2300 $\mathrm{Ma}$, but not in Archean rocks. In this study, some of the $2.5 \mathrm{Ga}$ yellowish gray cherts, particularly those with high LREE-enrichment, show small but distinct positive $\mathrm{Ce}$ anomalies. Banded cherts dated at $3.2 \mathrm{Ga}$ show no remarkable $\mathrm{Ce}$ anomalies and it is suggested that highly oxidizing conditions such as the present ocean were not favored for the formation of the Marble Bar Chert at 3.2 Ga. Among the banded cherts dated at $3.2 \mathrm{Ga}$, ironrich red bands often show slightly negative $\mathrm{Ce}$ deviations or positive La deviations, while silicarich and iron-poor white bands often show slightly positive Ce deviations or negative La deviations. The difference in $\mathrm{La} / \mathrm{Ce}$ behavior between red and white bands of banded cherts could provide information on different environments of precipitation between them.

Difference in geochemical features between the Marble Bar banded cherts and yellowish gray cherts: thermal event at $2.5 \mathrm{Ga}$

Differences in geochemical features between the banded cherts and yellowish gray cherts from Marble Bar are summarized as follows:

(1) Older Sm-Nd age for the banded cherts than the yellowish gray cherts; 3.2 and $2.5 \mathrm{Ga}$ for banded cherts and yellowish gray cherts, respectively.

(2) LREE-depleted or nearly chondritic values for initial $\varepsilon_{\mathrm{Nd}}(3.2 \mathrm{Ga})$ and $\varepsilon_{\mathrm{Ce}}(3.2 \mathrm{Ga})$ of banded cherts in contrast to LREE-enriched ones for the corresponding initial values at $2.5 \mathrm{Ga}$ of the yellowish gray cherts.

(3) Less scattering in $\mathrm{Rb}-\mathrm{Sr}$ isotopic data for the banded cherts than the yellowish gray cherts.

(4) Larger positive Eu anomalies for the banded cherts than the yellowish gray cherts.

(5) Clearer tetrad effect in REE patterns for the banded cherts than for the yellowish gray cherts.

(6) Lower $\mathrm{REE} / \mathrm{Fe}_{2} \mathrm{O}_{3}$ * ratios for the banded cherts than the yellowish gray cherts.

Judging from the isotopic results, it is clear that yellowish gray cherts were subjected to severe isotopic disturbance. The veins and clots of megaquartz observed in yellowish gray cherts suggest later thermal events. More depletion of $\mathrm{Fe}$ and wider scattering of $\mathrm{Rb}-\mathrm{Sr}$ isotopic data in yellowish gray cherts than banded cherts may imply that leaching during the thermal events was more intensive in the former cherts than the latter. Dur- 
ing the $2.5 \mathrm{Ga}$ events, the yellowish gray cherts might have suffered silicification with partial leach out of mobile elements such as Fe and less leach out of immobile elements such as REE. The alteration events seem to have partly modified even REE features and weakened the tetrad effect. Albert and McCulloch (1993) and Siddaiah et al. (1994) noted that the preservation of the tetrad effect in the Precambrian banded iron-formation was considered to be an indication of the undisturbed nature of REE geochemistry during postdepositional processes.

At the events under consideration, $\mathrm{Rb}-\mathrm{Sr}$ isotopic system was disturbed more intensely than $\mathrm{Sm}-\mathrm{Nd}$ system. As the result, $\mathrm{Rb}-\mathrm{Sr}$ isotopic data of the Marble Bar Chert do not give strict isochrons, but $\mathrm{Sm}-\mathrm{Nd}$ isotopic data do. LREE-enriched feature in initial $\varepsilon_{\mathrm{Nd}}(2.5 \mathrm{Ga})$ of the yellowish gray cherts is explained by rearrangement of Sm-Nd system in the cherts, on the assumption that Sm$\mathrm{Nd}$ isotopic data had been essentially common to both types of the cherts. $\varepsilon_{\mathrm{Nd}}(2.5 \mathrm{Ga})$ values around -5 is calculated from the Nd isotope evolution of the banded cherts and this value is observed for the initial $\varepsilon_{\mathrm{Nd}}(2.5 \mathrm{Ga})$ of the yellowish gray cherts.

The difference in geochemical features between banded cherts and yellowish gray cherts from the Marble Bar region may in large part be due to leaching, disturbance and/or rearrangement by thermal events at ca. $2.5 \mathrm{Ga}$ and in part to innate one. Sugitani (1992) reported a thin clastic layer containing sericite, detrital quartz, zircon and rutile in gray cherts. Original geochemical features of the yellowish gray cherts might have been different from those of the banded cherts, due to the presence of the detrital minerals. The existence of these clastic layers might have made the gray chert more permeable and suffered more intensely the geochemical perturbation than the banded cherts. It should be noted that the Marble Bar yellowish gray cherts do not always retain their original chemical features, while the banded cherts essentially retain their geochemical features, particularly for immobile elements such as REE. These results suggest that intense thermal events or metasoma- tisms took place in the Pilbara Block, although the Block is regarded as one of the best preserved early Archean crustal segments.

\section{ConClusions}

Sm-Nd age of $3.23 \pm 0.29 \mathrm{Ga}$ was obtained for the Marble Bar banded cherts from the Towers Formation of the Salgash Subgroup, the Warrawoona Group, and this age is thought to reflect the formational age of the banded cherts. It should be emphasized here that the $3.2 \mathrm{Ga} \mathrm{Sm-}$ Nd age for the Marble Bar banded cherts is the first authenticated geochronological data for the Archean cherts. The initial $\varepsilon_{\mathrm{Nd}}$ value of $+1.0 \pm 3.0$ appears to reflect their original feature at $3.23 \mathrm{Ga}$, although a slight perturbation by later events is conceivable. This initial $\varepsilon_{\mathrm{Nd}}$ value together with initial $\varepsilon_{\mathrm{Ce}}$ value of $-0.9 \pm 1.3$, abundances of $\mathrm{SiO}_{2}$ and $\mathrm{Fe}_{2} \mathrm{O}_{3}$ *, and positive Eu anomalies in REE patterns for the banded cherts support hydrothermal origin of the Marble Bar banded cherts. On the other hand, the Marble Bar yellowish gray cherts underwent later thermal events more severely than the banded cherts, and their geochemical features, such as degrees of $\mathrm{Ce}$ and $\mathrm{Eu}$ anomalies and tetrad effect in REE patterns, and $\mathrm{REE} / \mathrm{Fe}_{2} \mathrm{O}_{3}{ }^{*}$ ratios, became different from those of the banded cherts. The Sm-Nd data for the yellowish gray cherts are plotted around the $2.5 \mathrm{Ga}$ reference line. The age of $2.5 \mathrm{Ga}$ is considered to reflect the time of significant thermal events that occurred widely in the Pilbara Block.

Acknowledgments-We thank Dr. K. Takahashi and Mrs. S. Yabuki (The Institute of Physical and Chemical Research, RIKEN) for their help in major element and $\mathrm{Sr}$ isotopic ratio analyses. This work was supported in part by a Grant-in-Aid for Scientific Research from the Ministry of Education, Science and Culture of Japan.

\section{REFERENCES}

Albert, C. and McCulloch, M. T. (1993) Rare earth element and neodymium isotopic compositions of the banded iron-formations and associated shales from 
Hamersley, western Australia. Geochim. Cosmochim. Acta 57, 187-204.

Bickle, M. J., Bettenay, L. F., Chapman, H. J., Groves, D. I., McNaughton, N. J., Campbell, I. H. and deLaeter, J. R. (1993) Origin of the $3500-3300 \mathrm{Ma}$ calc-alkaline rocks in the Pilbara Archean: isotopic and geochemical constraints from the Shaw Batholith. Precambrian Res. 60, 117-149.

DePaolo, D. J. and Wasserburg, G. J. (1976) Inferences about magma sources and mantle structure from variations of ${ }^{143} \mathrm{Nd} /{ }^{144} \mathrm{Nd}$. Geophys. Res. Lett. 3, 743-746.

Derry, L. A. and Jacobsen, S. B. (1990) The chemical evolution of Precambrian seawater: Evidence from REEs in banded iron formations. Geochim. Cosmochim. Acta 54, 2965-2977.

Fryer, B. J. (1977) Rare earth evidence in iron formations for changing Precambrian oxidation states. Geochim. Cosmochim. Acta 41, 361-367.

Fryer, B. J., Fyfe, W. S. and Kerrich, R. (1979) Archean volcanogenic oceans. Chem. Geol. 24, 25-33.

Graf, J. L., Jr. (1978) Rare earth elements, iron formations and seawater. Geochim. Cosmochim. Acta 42, $1845-1850$.

Gruau, G., Jahn, B. M., Glikson, A. Y., Davy, R., Hickman, A. H. and Chauvel, C. (1987) Age of the Archean Talga-Talga Subgroup, Pilbara Block, Western Australia, and early evolution of the mantle: new Sm-Nd isotopic evidence. Earth Planet. Sci. Lett. 85, 105-116.

Hamilton, P. J., Evensen, R. K., O'Nions, R. K., Glikson, A. Y. and Hickman, A. H. (1981) Sm-Nd dating of the North Star Basalt, Warrawoona Group, Pilbara Block, Western Australia. Geol. Soc. Aust. Spec. Publ. 7, 187-192.

Hickman, A. H. (1983) Geology of the Pilbara Block and its environs. Geol. Surv. West. Aust. Bull., 127.

Hickman, A. H. and Lipple, S. L. (1975) Explanatory notes on the Marble Bar 1:250000 geological sheet, Western Australia. Geol. Surv. West. Aust. Rec., 1974/20.

Jahn, B.-M., Glikson, A. Y., Peucat, J. J. and Hickman, A. H. (1981) REE geochemistry and isotopic data of Archean silicic volcanics and granitoids from the Pilbara Block, Western Australia: implications for the early crustal evolution. Geochim. Cosmochim. Acta 45, 1633-1652.

Jahn, B.-M. and Shih, C.-Y. (1974) On the age of the Onverwacht Group, Swaziland Sequence, South Africa. Geochim. Cosmochim. Acta 38, 873-885.

Kolodny, J. and Epstein, S. (1976) Stable isotope geochemistry of deep-sea cherts. Geochim. Cosmochim. Acta 40, 1195-1209.

Lipple, S. L. (1975) Silica-rich pillow lavas near
Soanesville, Marble Bar 1:250000 sheet. Geol. Surv. West. Austr. Ann. Rep. 1972, 52-57.

Lowe, D. R. (1980) Archean sedimentation. Ann. Rev. Earth Sci. 8, 145-167.

Lugmair, G. W. and Marti, K. (1978) Lunar initial ${ }^{143} \mathrm{Nd} /{ }^{144} \mathrm{Nd}$ : differential evolution of the lunar crust and mantle. Earth Planet. Sci. Lett. 39, 349-357.

Makishima, A., Nakamura, E., Akimoto, S., Campbell, I. H. and Hill, R. (1993) New constraints on the ${ }^{138} \mathrm{La}$ $\beta$-decay constant based on a geochronological study of granites from the Yilgarn Block, western Australia. Chem. Geol. (Isotope Geos Sec) 104, 293-300.

Masuda, A. and Ikeuchi, Y. (1979) Lanthanide tetrad effect observed in marine environment. Geochem. J. 13, 19-22.

Masuda, A., Kawakami, O., Dohmoto, Y. and Takenaka, T. (1987) Lanthanide tetrad effects in nature: two mutually opposite type, W and $\mathrm{M}$. Geochem. J. 21, 119-124.

Masuda, A., Nakamura, T. and Tanaka, T. (1973) Fine structures of mutually normalized rare-earth patterns of chondrites. Geochim. Cosmochim. Acta 37, 239248.

Nagasawa, H. and Suwa, K. (1986) Rare-earth concentrations in 3.5-billion-year-old-Onverwacht cherts: An indicator for early Precambrian crustal environments. Geochem. J. 20, 255-260.

Nakai, S. (1988) Development of La-Ba geochronometer with its geochemical application. Ph.D. Thesis, Tokyo, University of Tokyo, $125 \mathrm{pp}$.

Oversby, V. M. (1976) Isotopic ages and geochemistry of Archaean acid igneous rocks from the Pilbara, Western Australia. Geochim. Cosmochim. Acta 40, 817-829.

Pidgeon, R. T. (1978) 3450 m.y. old volcanics in the Archaean layered greenstone succession of the Pilbara Block, Western Australia. Earth Planet. Sci. Lett. 37, 421-428.

Richards, J. R. (1978) Lead isotopes and ages of galenas from the Pilbara region, Western Australia. $J$. Geol. Soc. Aust. 24, 465-473.

Shimizu, H., Amano, M. and Masuda, A. (1991) La$\mathrm{Ce}$ and Sm-Nd systematics of siliceous sedimentary rocks: A clue to marine environment in their deposition. Geology 19, 369-371.

Shimizu, H. and Masuda, A. (1977) Cerium in cherts as an indication of marine environment of its formation. Nature 266, 346-348.

Shimizu, H., Nakai, S., Tasaki, S., Masuda, A., Bridgwater, D., Nutman, A. P. and Baadsgaard, H. (1988) Geochemistry of Ce and Nd isotopes and REE abundances in the Amitsoq gneisses, West Greenland. Earth Planet. Sci. Lett. 91, 159-169.

Shimizu, H., Tanaka, T. and Masuda, A. (1984) Mete- 
oritic ${ }^{138} \mathrm{Ce} /{ }^{142} \mathrm{Ce}$ ratio and its evolution. Nature 307, 251-252.

Siddaiah, N. S., Hanson, G. N. and Rajamani, V. (1994) Rare earth element evidence for syngenetic origin of an Archean stratiform gold sulfide deposit, Kolar schist belt, south India. Econ. Geol. 89, 1552-1566.

Steiger, R. H. and Jäger (1977) Subcommission on geochronology: Convention on the use or decay constants in geo- and cosmochronology. Earth Planet. Sci. Lett. 36, 359-362.

Sugitani, K. (1992) Geochemical characteristics of Archean cherts and other sedimentary rocks in the Pilbara Block, Western Australia: evidence for Archean seawater enriched in hydrothermally-derived iron and silica. Precambrian Res. 57, 21-47.

Tanaka, T. and Masuda, A. (1982) The La-Ce geochronometer: A new dating method. Nature 327, 113-117.

Taylor, S. R. and McLennan, S. M. (1985) The Continental Crust: Its Composition and Evolution. Blackwell, Oxford, England, 312 pp.

Thorpe, R. I., Hickman, A. H., Davis, D. W., Mortensen, J. K. and Trendall, A. F. (1992) U-Pb zircon geochronology of Archaean felsic units in the Marble Bar region, Pilbara craton, Western Australia. Precambrian Res. 56, 169-189.
Wasserburg, G. J., Jacobsen, S. B., DePaolo, D. J., McCulloch, M. T. and Wen, T. (1981) Precise determination of $\mathrm{Sm} / \mathrm{Nd}$ ratios, $\mathrm{Sm}$ and $\mathrm{Nd}$ isotopic abundances in standard solutions. Geochim. Cosmochim. Acta 45, 2311-2323.

Weis, D. and Wasserburg, G. J. (1987a) Rb-Sr and SmNd systematics of cherts and other siliceous deposits. Geochim. Cosmochim. Acta 51, 959-972.

Weis, D. and Wasserburg, G. J. (1987b) Rb-Sr and $\mathrm{Sm}$-Nd isotope geochemistry and chronology of cherts from the Onverwacht Group (3.5 AE), South Africa. Geochim. Cosmochim. Acta 51, 973-984.

Wildman, T. R. and Haskin, L. A. (1973) Rare earths in Precambrian sediments. Geochim. Cosmochim. Acta 37, 419-438.

Yamamoto, K. (1987) Geochemical characteristics and depositional environments of cherts and associated rocks in the Franciscan and Shimanto Terranes. Sediment. Geol. 52, 65-108.

Yamamoto, K. (1991) Major and minor element geochemistry and depositional environment of siliceous sedimentary rocks. Chikyukagaku (Geochemistry) 25, 17-26 (in Japanese with English abstract).

York, D. (1966) Least squares fitting of a straight line. Can. J. Phys. 44, 1079-1086. 